\title{
Inequality and transaction costs in a community-based water supply in rural area adjacent to national park
}

\author{
Ambar Istiyani ${ }^{1 *}$ and Mohamad Shohibuddin ${ }^{2}$ \\ ${ }^{1}$ Sekolah Tinggi Ilmu Ekonomi AMA Salatiga, Indonesia \\ ${ }^{2}$ Bogor Agricultural University, Bogor, Indonesia \\ *Correspondence email: ambar@stieama.ac.id
}

\section{ARTICLE INFO}

- Research Article

Article History

Received 27 December 2020

Accepted 16 March 2021

Published 17 April 2021

\section{Keywords}

collective action; inequality; national park; transaction cost; water supply

\section{JEL Classification} D23; P48; Q15

\begin{abstract}
National parks can be sensitive state-property areas since the surrounding communities generally need the parks' resources for their livelihood. This paper focuses on inequality and transaction costs in PAMSIMAS (Community-Based Water Supply and Sanitation), a water sector program in Indonesia's rural and peri-urban areas. The method used is a case study of PAMSIMAS in Tajuk, a village adjacent to Mount Merbabu National Park in Semarang Regency, Central Java. The data were gathered from documentary studies, in-depth interviews, and observations, and were analyzed using transaction cost economics and institutional analysis. This study found that the rules of PAMSIMAS, especially water pricing mechanisms, enhanced water availability but could not diminish the uncertainty of water access and transaction costs born by water users. Inequalities of endowment, power, and information among the hamlets affected how PAMSIMAS was run. Mobilization of water resources is related to property rights, which should be well-defined. Still, there was an overlapping property institution of Mount Merbabu National Park forest and its water resources; thus, the water user groups had to bear different transaction costs. The study provides suggestions for providing broader 'rules of the game' in rural water management, recognizing local conditions and prospects, acknowledging community rights to resources, and developing inclusive community participation.
\end{abstract}

To cite this article: Istiyani, A. \& Shohibuddin, M. (2021). Inequality and transaction costs in a community-based water supply in rural area adjacent to national park. Journal of Socioeconomics and Development, 4(1), 94-108. https://doi.org/10.31328/jsed.v4i1.1866

ISSN 2615-6075 online; ISSN 2615-6946 print (C)WG Press, 2021

\section{INTRODUCTION}

Pengelolaan Air Minum dan Sanitasi Berbasis Masyarakat (PAMSIMAS) or Community-Based Water Supply and Sanitation) is a community water sector program encouraging communal participation in managing drinking water and sanitation in Indonesia's rural and peri-urban areas. The program refers to Indonesian Law No. 32 on Regional Government and Law No. 33 on Financial Balance between Central and Regional Government that mandates the government to provide basic necessities for the community, including drinking water and sanitation. Additionally, PAMSIMAS refers to Indonesia's commitment to achieving the Millennium Development Goals for the Water Supply and Sanitation Sector (currently the sixth goal of the Sustainable Development Goals). The program involves five Indonesianministries (Ministry of Public Works, National Development Planning Agency - BAPPENAS, Home Affairs, Health, and Villages for Disadvantaged Areas and Transmigration) with the 
supports from international donor agencies, namely The World Bank and The Australian Government Department of Foreign Affairs and Trade.

By 2020, PAMSIMAS has reached thousands of villages and peri-urban areas throughout Indonesia. PAMSIMAS I started from 2008 to 2012, targeting 7,402 rural and peri-urban areas, then PAMSIMAS II continued in 2013-2017, targeting 5,297 villages and peri-urban areas (The World Bank, 2014). To achieve the target of Universal Access to Drinking Water and Sanitation in 2019, PAMSIMAS III continued to increase the number of low-income rural and suburban residents who can access better water and sanitation facilities and better hygiene practices. The World Bank reports that the institutional sustainability of the PAMSIMAS approach shows positive signs, and even $97 \%$ of regencies replicate the path outside the target communities (Wray, 2019). With this success stories, this program will continue in the years to come.

Many researches and evaluations on PAMSIMAS implementation have shown success stories of the program, including increasing access to drinking water and community participation. It is now easier for rural communities to get clean water and sanitation facilities (Pratama \& Isnanik, 2018; Sitranata, 2016). This is coupled with the high utilization and maintenance of water supply and sanitation infrastructure (Fitriyani \& Rahdriawan, 2015; Suroso, 2018). Participation in PAMSIMAS is in the form of community involvement in decision-making and the spending of energy and money for the program's sustainability (Chaerunissa, 2014). PAMSIMAS has encouraged success in increasing community participation in water supply and sanitation that, in fact, in some areas, the achievement of the program has exceeded the targets (Asminar, 2019; Chaerunissa, 2014).

Although many success stories of PAMSIMAS have been demonstrated by the above studies, yet other studies and evaluations also show several issues in the program implementation that need to be addressed, including water quality and inequality problems. In several rural and urban areas, clinical trials of water quality are critical because of inadequate water quality (Fitriyani \& Rahdriawan, 2015). PAMSIMAS implementation evaluation also shows that the development of PAMSIMAS infrastructure has not been evenly distributed (Suroso, 2018). In Pati Regency, for example, only $26.85 \%$ of villages have access to the program (Suroso, 2018).
Research on PAMSIMAS implementation in the areas adjacent to national parks has not been done much. National parks can be sensitive state-property areas since the surrounding communities generally need the parks' resources for their livelihood. To protect wildlife and biodiversity, state institutions restrict human access to parks, so behind the success of conservation, conflicts and violence between the state agency and community often occur (De Pourca et al., 2017; Mukherjee, 2009). The root of the conflict varies greatly, not only from the state's political priorities but also from various actors with various interests and needs (Sandlos, 2007; Vedeld et al., 2012). Besides, several studies found that conservation benefits through national parks may increase local economic inequality (Ntuli \& Muchapondwa, 2017; Tumusiime \& Sjaastad, 2014). Actors with more wealth or power are more likely to have more access to the national park resources than the poor ones.

Sharing the benefits and costs among individuals in resource use is significant in collective action. The inequality of endowments may affect the distribution of benefits and costs (Bardhan et al., 2018). The distribution of access rights to the common-pool resources and its benefits tends to reflect the distribution of wealth endowments, so wealthier users could benefit more from managing resources than relatively poorer users (Kurian \& Dietz, 2013). Economic endowments, social norms, and social perceptions such as class, caste, ethnicity, gender can also affect how resources are allocated. Unequal distribution of access rights may lead to unstable and hostile relations among individuals. Thus individuals with fewer endowments will feel uncertain about their future rights (Baland \& Platteau, 2018).

Understanding the performance of water sector programs requires a thorough cost analysis, not only the costs of the program implementation process but also the transaction costs involved (Laurenceau et al., 2009). McCann (2013) defined transaction costs as the resource costs of creating and using policies by defining, assigning, maintaining, and transferring property rights. Meanwhile, Ostrom (2015) distinguished transaction costs by comparing them with transformation activities/costs. Transformation activities change a situation into something else, such as building a water reservoir in an irrigation system. Meanwhile, transaction activities are directed at (i) coordinating transformation activities, (ii) providing 
information, and (iii) gaining strategic over other advantages. All transformation activities in collective action will include transaction activities, or,as some may call it, collective lobbying activities (Meinzen-Dick et al., 2002). They require transaction costs for which large amounts of time, money, and energy are consumed.

The focus of transaction cost economics is the disputes that may arise when individuals, characterized by bounded rationality and opportunistic behavior, are involved in contractual relationships (Williamson, 2019). Relationships between individuals who do not have the same information, incentives, resources, and social norms may give rise to transaction activities and the resulting costs (Ostrom, 2015). This situation encourages some individuals to adopt opportunistic strategies to obtain unequal benefits at others' expense, namely "free ride," rentseeking, and corruption.

Many studies have widely described transaction costs addressing water management, water market, and policy on water (Deng et al., 2018; Njiraini et al., 2017; Zhang et al., 2013). Arifin (2006) explicitly described the transaction costs of the upstream and downstream relations in community-based forest and water management in protected areas. However, the study has not linked the transaction costs with the problem of inequalities between actors in resources management. Inequalities are very likely to drive an increase in transaction costs, thereby reducing the level of certainty in sustainable water management (Ostrom, 2015).

This study examines inequalities affecting the efficiency of transaction costs in community-based water management by taking a case study of PAMSIMAS program implementation. A better understanding of the performance of PAMSIMAS in sensitive areas like national parks will provide input for future development of the programs and public services. This study is expected to give policy recommendations, especially in improving water supply and sanitation programs in rural areas.

\section{RESEARCH METHOD}

The method used was a case study of PAMSIMAS program implementation in Tajuk, a village adjacent to Mount Merbabu National Park in Getasan District, Semarang Regency, Central Java Province, Indonesia. The parts of the research problem and its relationship are stated as follows. The issue of inequality has relevance to transaction costs. Inequalities in this study are the power, endowment, and information owned by water user groups involved in the PAMSIMAS program. Meanwhile, transaction costs are costs from lobbying and negotiation activities to access water resources that built contractual relationships among water users.

Data were collected using the triangulation method. The documentary study was used to obtain data related to the general overview of the village and PAMSIMAS Program. The document sources were from the village government, the Ministry of Public Works, and Mount Merbabu National Park). In-depth interviews to obtain primary data by interviewing key respondents such as the village apparatus, national park staff, and water users in each hamlet (subvillage).Observations were done to obtain data related to the biophysical condition of the village, community socio-economic activities, and water management infrastructure.

This study used transaction cost economics and institutional analysis, considering that transaction costs efficiency is essential for all organization forms, including those involved in managing common-pool resources (Ostrom, 2015). In this study, the said institutions were (i) the property rights regulating access to forest and water resources in the zone of the national park, and (ii) the program rules in PAMSIMAS providing coordination functions for community-based water management. It was then reviewed whether under these two institutions, water users' transaction costs to get water access becoming more efficient.

\section{RESULT AND DISCUSSION}

\section{Description of The Study Area}

Tajuk Village is located on the slope of Mount Merbabu, Getasan District, Semarang Regency, Central Java Province, Indonesia (Figure 1) and has a wealth of potential resources. Mount Merbabu has about 5,725 ha of dense forest areas which consists of pines, acacia, flowers, and bushes. These forest areas are the primary and upstream catchment areas of 17 rivers in Magelang, Semarang, and Boyolali Regencies (Gunawan et al., 2013). The slopes of Mount Merbabu have many springs, which release 10,055 liters/second of water, so that in a year, there is around 312.75 billion cubic meters of water. Thus, Mount Merbabu 
has abundant water resources that the local community can utilize.

The village consists of eleven hamlets (subvillages) whose elevations range from 1,000 meters to 1,800 meters above sea level and has an average air temperature of 13 to $23^{\circ}$ Celsius. Seven of the eleven hamlets are directly adjacent to the border of the Mount Merbabu National Park. This village has many springs located both in the village area and in the national park zone. The local community recognizes the riparian right, where every hamlet with a land boundary next to spring can fetch its water.

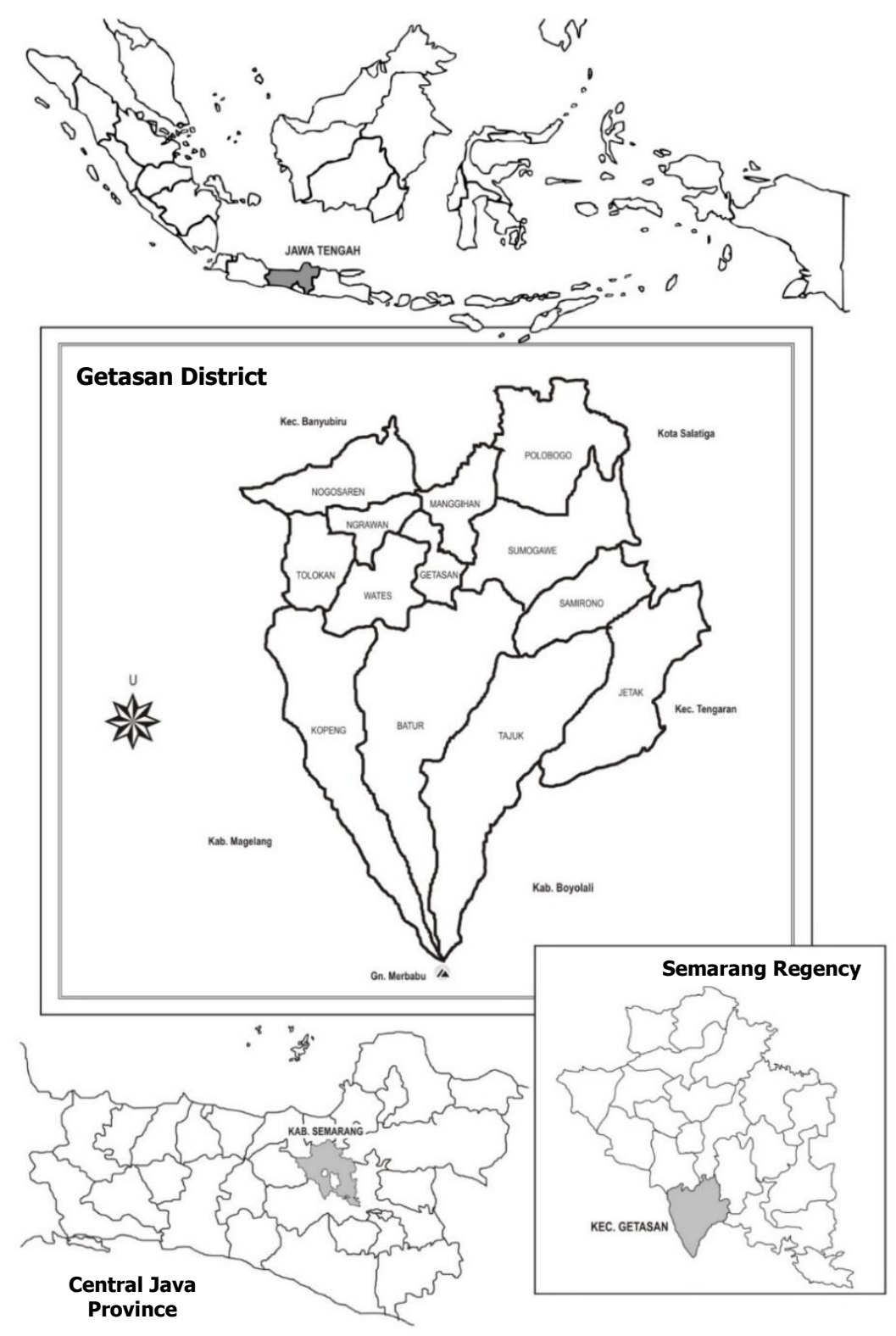

Figure 1. Map of the study location 
Table 1. Major Changes in the Property System of Mount Merbabu Forest

\begin{tabular}{ll}
\hline Period & Changes in Forest Status and its Management Institutions \\
\hline $\begin{array}{l}\text { Pre-Independence Era } \\
1906\end{array}$ & $\begin{array}{l}\text { Tribal rules. } \\
\text { Set as 'the forbidden forest' ( hutan larangan/tutupan) by the Dutch Colonial Government. } \\
\text { Designation of forest boundaries based on Proces verbaal van grensregeling (Berita Acara Tata } \\
\text { Batas/Notes of the Boundary) for Kedu Area (in Muntilan and Tegalrejo District) and Boyolali } \\
\text { Regency. } \\
\text { Designation of forest boundaries for Semarang Regency area, including Village communities, } \\
\text { lived in the forest called enclaves. }\end{array}$ \\
$\begin{array}{l}\text { Recognition endorsement of designated boundaries as having de facto and de jure status, } \\
\text { resulting from Grensprojectkaart (forest mapping). }\end{array}$ \\
$\begin{array}{l}\text { Post-Independence Era } \\
1959-1963\end{array}$ & $\begin{array}{l}\text { Forest management by Forestry Office at the regency level. } \\
\text { Forest management by Perhutani, a BUMN (state-owned enterprise) that managed most forest } \\
\text { areas in Java. }\end{array}$ \\
$\begin{array}{l}\text { Forest management by Central Government through the Ministry of Forestry following the change } \\
\text { of forest function into national park which designated zones system with specific provisions for } \\
\text { each zone. }\end{array}$ \\
\hline Source: From various sources and interviews with local people and a staff of Mount Merbabu National Park
\end{tabular}

Source: From various sources and interviews with local people and a staff of Mount Merbabu National Park

Most of the villagers are indigenous people, inhabiting the area for several generations, so they have strong social ties, both with fellow residents (bonding social capital) and nature. Communities depend on forest resources, such as wood for fuelwood, grass for animal feed, and water from springs located in the national park's forest zone. Around 4,007 people live in Tajuk, and mostly (87.44\% of the total workforce) work as farmers or laborers. Only a small proportion of workers are fully employed in other sectors, such as civil servants, military/police officers, tailors, drivers, private sector employees, carpenters, masons, and private teachers.

Collective action for water resources management occurs independently in each hamlet. The rules that define the tasks and participation among them are developed and enforced on their own. Thus, in general, there is only one water supply system in each hamlet. Some hamlets use neighborhood groups at the local level, such as RT (Rukun Tetangga/neighborhood association) or RW (Rukun Warga/citizens association), as water resources management organizations. Several other hamlets form a special team to manage water resources.

Each hamlet's independent management is due to geographical and administrative boundaries and each hamlet's social identity. Geographical boundaries that separate the hamlets include rivers, agricultural land, and forests. The Dusun (hamlet) identity is more potent than village identity, even though all people live in the same village. Phrases like Wong Pulihan or Wong Kaliajeng (a native or inhabitant of Pulihan
Hamlet or Kaliajeng Hamlet) indicate a social identity embedded in their collective memory. Another social identity entrenches in their belief in the communal tradition, i.e.Saparan. Each hamlet has its own belief about a good day to celebrate this tradition that refers to their respective Danyang (the village founder or protector spirit)

\section{Institutional Arrangement}

\section{Mount Merbabu National Park}

In 1980, coinciding with the World Conservation Strategy's announcement, Indonesia's government implemented the national park concept. The criteria for determining national parks in Indonesia are regulated and confirmed in Law No. 5 of 1990 concerning Conservation of Living Natural Resources and their Ecosystems and Law No. 41 of 1999 concerning Forestry and various implementing regulations.

In terms of ownership, national parks are generally state property, although the states sometimes give restitution to indigenous people's land (Curry, 2009). In Indonesia, the central government is the leading manager of national parks through the Ministry of Forestry. Meanwhile, the technical implementation unit at the site is the National Park Office under the Directorate General of Natural Resources Conservation. Along the way, based on the agreement of the WCPA (World Commission on Protected Areas) Congress in 1993, conservation areas cannot only be managed by a single institution. The management must involve various concerned parties, especially the 
community around the area (Dunggio \& Gunawan, 2009).

The property system of Mount Merbabu forest has changed several times. Table 1 shows institutional changes on Mount Merbabu forest concerning its property system. After Indonesia's independence, it was managed by the Forestry Department of Indonesia at the regency level. Subsequently, in 1963, Perhutani (state-owned enterprise) managed some parts of the forest as a timber production source. Finally, in 2004, the Ministry of Forestry of Indonesia took over the management and changed the forest function as a national park.

The government divided the the national park area into several zones: (i) the core zone, i.e. a part the national park that is protected, serving to protect the representation of the original and unique biodiversity; (ii) the jungle zone, i.e. a part that, due to the location, the conditions and its potential, can support the interests of conservation in the core zone and the zone of utilization; (iii) the utilization zone, i.e. a part where the natural conditions and potentials are mainly utilized for the benefit of nature tourism and other environmental conditions/services; (iv) traditional zone, i.e. a part that is determined for the benefit of traditional use by the local community who due to their historical background has a strong dependency on natural resources; $(v)$ rehabilitation zone, i.e. a part that needs to be restored since the living community and its ecosystem is damaged; and (vi) cultural zone, i.e. a part in which there are religious sites, cultural and or historical heritage used for religious activities, and protection of cultural or historical values.

Institutional change of the forest into Mount Merbabu National Park affects the relationship between the local community and the forest and its resources. The central government established a government agency responsible for the management of national park. Local people's activities must be adjusted according to the national park's zone designation, although most of them do not understand this system. Some hamlet residents are still allowed to manage the land called lacen in the utilization zone, which used to be obtained from the community-based forest management program (PHBM) when the government organizes the Merbabu mountain forest area as a production forest (Gunawan et al., 2013). Thus, local people may still benefit from forest resources but must comply with state regulations and government agencies responsible for the forests. For instance, in the context of local wood needs, the community cannot cut down and take advantage of forest trees, even trees that have already fallen. There is a rule that fallen trees must be returned to nature by burying them in the forest's ground. Entering the woods with a rifle is also illegal, while incidentally, the local people need to drive out monkeys that often destroy their crops.

The constraints that the government imposes have sometimes created tension between government agencies carrying out state duties and the locals fighting for their livelihoods. For instance, in Sokowolu Hamlet, Tajuk Village, a physical fight between six national park forest rangers had occurred in Sokowolu. The violence that led to the burning of a motorbike belonging to one of the officers was a response to allegations of an elderly villager as being committed in illegal logging. Patrol officers also detained a local resident for carrying a rifle which the resident used to repel a herd of monkeys that destroyed agricultural land. The officers finally released the local resident after the hamlet leader threatened to mobilize the crowd to the detention location. These incidents are in line with the research of De Pourcq et al. (2017) and Mukheriee (2009), namely that conservation policies in national park areas that are insensitive to the needs of local communities are very likely to cause conflict and violence between local communities and the state agency.

There has not been much change in how the local community access water sourced from the national park, but it must comply with applicable regulations. The community can still use water, but only in permitted zones such as the utilization and traditional zones. The locals cannot build and/or rebuild water storage tanks in the restricted zone. There are also variations in how the hamlets in Tajuk Village get their water from the national park areas. Apart from being related to the state-property embedded in the national park, this variation is related to the principle of riparian rights recognized by village communities which means the people closest to the water source are more entitled to access these resources (Craig, 2012). Common variations are (i) communities directly adjacent to the national park can access water straight from the source, and (ii) hamlet communities that are not directly adjacent to the national park can access water, but through coordination with hamlets directly neighboring the national park. Some hamlets also provide water management services to parties outside 
the village, such as Salatiga City areas, which are relatively remote.

\section{PAMSIMAS}

In 2013, Tajuk Village received a grant from the government for the PAMSIMAS program by complying with the government's strict rules. These strict rules are part of an effort to change people's behavior and habits within a development project framework ( $\underline{\mathrm{Li}}$, 2016). The village must compete with other villages in the regency. They must make program proposals to Semarang Regency government and meet some requirements set by the policy makers (the government and the World Bank). The requirements included (i) villages were capable of providing Community Empowerment cadres in the Water and Sanitation sector; (ii) the community had to provide an endowment fund in $4 \%$ in cash and $16 \%$ in kind; (iii) the community must get used to healthy sanitation behavior and bear the costs of transformation activities. After fulfilling these requirements, Tajuk Village received a grant from the State Budget amounting to 216 million rupiahs.

Apart from the rules that the village must meet before program implementation, other rules needed to be implemented during program implementation. These rules were embedded in the technical manuals for ensuring the performance of PAMSIMAS. To implement these regulations, program implementers received various training and technical guidance facilitated by the government. The rules that significantly change water management under PAMSIMAS Tajuk Village are (i) the adoption of a water pricing mechanism; (ii) the obligation for the community involved in PAMSIMAS to install a water use meter; and (iii) the establishment of Water Supply and Sanitation Facility Management Agency (BPSPAMS) as a new collective-choice body. Table 2 shows more details regarding the major rules under the PAMSIMAS program in Tajuk Village.

Of these main rules in PAMSIMAS, the rule that makes water availability higher is the volumetricbased water pricing mechanism. The mechanism can provide incentives for more efficient water use (Narasimhan, 2016). The users must bear the opportunity cost of using water. Based on an interview with a farmer, water use became more efficient after the implementationof PAMSIMAS. Some farmers said that they were worried about using water excessively so that the costs would be high. Thus, water is more available, especially for farmers living in the lower terrain who used to face water shortage. In other words, the market-like institution under PAMSIMAS has resulted in water use efficiency, which means that all water users get sufficient water.

However, the problem usually arises with regard to how a reasonable price can be determined (Chen et al., 2013). Initially, the community responded to this rule with pros and cons. Most of the farmers witha lot of livestock objected to the regulation because they were worried that they would pay a high-water price. Meanwhile, people who mostly live in lower areas strongly agreed. They considered that people living in higher areas used water excessively. Thus, residents in lower areas often experienced water shortages. The whole community ultimately agrees with the rules regarding the cost of water as long as they decide it themselves, and the water price will not be as high as in urban areas

Table 2. Major Rules of Water Management under PAMSIMAS in Tajuk Village

\begin{tabular}{|c|c|}
\hline Major Rules & Consequences \\
\hline $\begin{array}{l}\text { 1. The adoption of a water } \\
\text { pricing mechanism (a } \\
\text { market-like mechanism) }\end{array}$ & $\begin{array}{l}\text { - A volumetric water pricing is enacted (water charge is based on the amount of water used). } \\
\text { - All water users have to pay monthly abonnement and the charge of water counted per } \\
\text { cubic meter }\end{array}$ \\
\hline $\begin{array}{l}\text { 2. The obligation to install } \\
\text { new technology, mostly } \\
\text { water meter in each house }\end{array}$ & $\begin{array}{l}\text { - The water system is designed as a closed pipeline network to control water transfer. } \\
\text { - Smaller pipes connect the main water storage tank to water users' houses. With a gravity } \\
\text { system, water flows from the water storage tank to the downstream area. } \\
\text { - Water meter/calculator is installed in each house to count the amount of water usage per } \\
\text { household. } \\
\text { - Water users who have installed this machine have automatically joined the program. }\end{array}$ \\
\hline $\begin{array}{l}\text { 3. The establishment of a new } \\
\text { collective-choice body }\end{array}$ & $\begin{array}{l}\text { - Changes in stewardship in water management from the leaders of RTs to the BPSPAMS, as } \\
\text { a new collective choice body. } \\
\text { - Members of the BPSPAMS have authority over daytoday management, including operation } \\
\text { and monitoring. }\end{array}$ \\
\hline
\end{tabular}




\section{Inequalities}

With the amount of the fund granted (216 million rupiahs), the program could only reach a limited number of houses in the village. Of the 969 houses in Tajuk Village, only 207 could benefit from PAMSIMAS. Thus, only two hamlets, namely Hamlets of Pulihan and Kaliajeng, could be involved in the program. All houses (140 houses) in Pulihan and a number of the houses (67 houses) in Kaliajeng got the privilege to join the program. Besides, two parties outside the village, an agricultural company and a social foundation, were allowed to join at their own expense. Table 3 shows the groups of water users in the PAMSIMAS program in Tajuk Village.

Table 3. Water Users within PAMSIMAS System in Tajuk Village

\begin{tabular}{|c|c|c|}
\hline Water Users & $\begin{array}{c}\text { Number } \\
\text { Users }\end{array}$ & Water Uses \\
\hline Pulihan inhabitants & 140 & $\begin{array}{l}\text { Domestic use and } \\
\text { agricultural production }\end{array}$ \\
\hline Kaliajeng inhabitants & 67 & $\begin{array}{l}\text { Domestic use and } \\
\text { agricultural production }\end{array}$ \\
\hline Agricultural company & 1 & $\begin{array}{l}\text { Livestock production } \\
\text { business }\end{array}$ \\
\hline Social institution & 1 & $\begin{array}{l}\text { Social activities and } \\
\text { hospitality business }\end{array}$ \\
\hline
\end{tabular}

The two hamlets joining PAMSIMAS, Pulihan and Kaliajeng, have differences in bio-physical condition and endowment. Pulihan has a better advantage in biophysical conditions since it has several abundant alternative water sources in its area. Its location is also in the upper terrain and adjacent to the national park zone where the spring for PAMSIMAS locates. With the principle of riparian rights believed among the villagers, Pulihan has the right to fetch water from the closest park's zone. Meanwhile, Kaliajeng is located lower than Pulihan. Although it has several alternative water sources, it is not sufficient for all inhabitants. Kaliajeng has quite a large spring, but its location is in an area under its residential terrain, so they cannot use a gravity system that facilitates water distribution. Moreover, they do not have sufficient technology to drain water from the bottom to the top. Therefore, Kaliajeng must seek access to water from Pulihan.

Biophysical conditions and endowments of different water users in the village have alluded to who will receive more benefits from PAMSIMAS. Ostrom (2010) suggested that biophysical and material conditions may affect how resources and property are distributed or restricted. With that unequal situation, Pulihan got more opportunities to allow all its residents could be involved in PAMSIMAS, while Kaliajeng did not get the same chance. Kaliajeng must get 'generosity' from Pulihan to get water access. This confirms Kurian \& Dietz's (2013) research results that resource users with more endowments will benefit more than those who do not.

Apart from biophysical conditions, power asymmetries also affect how development programs are implemented in Tajuk. García \& Bodin (2019) suggested that participation in various forums is the key to influence decision-making in water governance. Pulihan has become more robust due to several local political elites residing there. The village office is located in Pulihan, and some people holding strategic positions as village officials also lived in Pulihan, including the village head and village secretary. Besides, a resident of Pulihan worked for national park office and all members of BPSPAM as the collective choice body were Pulihan residents. These strategic positions gave Pulihan more opportunities to participate and more power to influence decisionmaking processes than other hamlets.

Power asymmetries, in turn, also intersect with asymmetric information of different groups (Saam, 2007). Since elites' strategic positions were mostly concentrated in Pulihan, information on development programs, especially from the top-level government and the national park agency, ranmostly to Pulihan. The national park staff from Pulihan mostly coordinated more conservation programs with the government and various civil society organizations (CSOs) outside the village. This unequal access to information is very likely to impact development programs significantly, especially if it is not transparent (Lightfoot \& Wisniewski, 2014). A hamlet head who did not receive the PAMSIMAS program even expressed a despair feeling and stated, in a satirical tone, "let Pulihan be full first." This shows how Pulihan enjoyed more and earlier development programs than other hamlets.

Furthermore, there is a power imbalance between the surrounding rural communities and the national park management. In the context of state-centered management of national parks, the state has expanded its power (Lunstrum, 2013). To access resources from national parks, neighboring rural 
communities must follow rules that promoted conservation. Even though local communities recognized riparian rights and felt they own water resources close to them, the national park resources are legally a state property. Enforcement usually follows the zoning system of the national park and the restrictive rules embedded in it. What is often worrying is the exerciseof law enforcement with a militaristic approach, which sometimes worsens the relationship between the national park and the surrounding village communities (Lunstrum, 2014).

\section{Transaction Costs and Uncertainty}

Unequal relations among water user groups in PAMSIMAS increased transaction activities which in turn increase costs incurred. This is in line with Ostrom's insight (2015) that transaction costs are very likely to be high if individuals have different information, incentives, resources, and social norms. As described above, Pulihan and Kaliajeng have differences in biophysical conditions, power, and information. Meanwhile, there is an imbalance in power relations between the state that manages the national park and the surrounding village communities. Characteristics of water user groups, such as bounded rationality and opportunism, also impact increasing transaction costs in the development program (Coggan et al., 2013). In the case of PAMSIMAS in Tajuk, user groups prioritized the interests of their respective groups.

In the water market, property rights significantly affect transaction costs (Williamson, 2015). The PAMSIMAS water source in Tajuk is located in the national park area. There is an overlapping institutional arrangement to this water source. The rural communities believed they had the right to use the water source because they recognized riparian rights. Pulihan is close to the water source, therefore acknowledging ownership to the resource and rights to transfer access and distribute water to other parties they agree with. Meanwhile, the government considered that it is legally a state property. The parties who wished to gain water access should carry out transaction activities and incur transaction costs.

There were several forms of transaction costs in implementing PAMSIMAS in Tajuk. Firstly, transaction activities in the form of lobbying for the collective interests of each water user group. Kaliajeng needed to negotiate with Pulihan to keep getting water allocation and getting involved in the PAMSIMAS program. The head of Kaliajeng hamlet met directly with the village secretary, a resident of Pulihan, several times to discuss the possibility of Kaliajeng getting access to water. These meetings were held at the village office and the village secretary's house. During the dry season, Kaliajeng would ask Pulihan to allocate water to them. In the rainy season, Kaliajeng would ask them to stop the distribution because the water sourced from the springs in Kaliajeng has met all its residents' needs. Meanwhile, although not as often as Kaliajeng, Pulihan must also negotiate with the national park authorities to ensure that they could still access water sourced from the national park area. The lobbies were facilitated by the non-civil servant national park staff living in Pulihan.

The lobby and search for information activities required money and effort. Money was explicitly needed, especially for the cost of transportation. In every effort to find information, a hamlet representative visited the targeted parties, so they had to leave their job. Implicitly, costs were incurred in actors' labor and time spent in information seeking or supervision. If converted to the average standard wages per day received by local people as laborers working in fields/ agricultural land, the transaction costs incurred were around 60,000 - 70,000 rupiahs for each time information inquiry process was done. Therefore, Kaliajeng spent more time and resources to negotiate with local elites and BPSPAMS. Negotiations allowed Kaliajeng to continue to access water through PAMSIMAS under the coordination of Pulihan.

Table 4. Contribution Fee of Water Usage

\begin{tabular}{lcc}
\hline Water Users & $\begin{array}{c}\text { Tariff of } \\
\text { Household }\end{array}$ & $\begin{array}{c}\text { Tariff of Using } \\
\text { Water }\end{array}$ \\
\hline rupiah/month & rupiah/m ${ }^{3}$ \\
Pulihan inhabitants & 1,000 & 200 \\
Kaliajeng inhabitants & 3,000 & 200 \\
Agricultural company & - & 3,000 \\
Social institution & - & 3,000 \\
\hline
\end{tabular}

Secondly, other transaction cost was in the form of contractual relationships among groups of water users. Volumetric-based water pricing rules applied to all water users and were managed by BPSPAMS as the collective choice body. The two hamlets were involved in a contractual relationship through the settlementof different water tariffs. Table 4 shows that the costs incurred by each sub-group are uneven. As a part of the unwritten contractual agreement, the residents of Kaliajeng paid a higher tariff than the residents of 
Pulihan. To continue to get water distribution, however, Kaliajeng must agree to the water tariff decision determined by Pulihan.

Following the transaction costs spent, there was uncertainty regarding water access for each hamlet involved in PAMSIMAS. As embedded in riparian rights, residents of Pulihan had the right to be more prioritized over water access than Kaliajeng or other parties. This means that water users with more endowments will benefit from the management (Kurian \& Dietz, 2013). Thus, Kaliajeng depended more on the 'generosity' of Pulihan. While unwritten, there was a mutual agreement between Pulihan and Kaliajeng in which Pulihan would be given a priority in getting water supply during the dry season. Kaliajeng's condition was relatively weak because access to water was only obtained after Pulihan's water needs were fulfilled first. This indicates that the group with lower power or endowment will feel uncertain in getting resources (Baland \& Platteau, 2018).

This uncertain situation ended in 2018 when the tension between Pulihan and Kaliajeng peaked. Pulihan asked for a tariff increase for Kaliajeng of 5,000 rupiahs per month due to the construction and reparation of pipes. Kaliajeng objected this unilateral decision, so they were not willing to pay. Pulihan then decided to stop water distribution to Kaliajeng. After five years of PAMSIMAS in Tajuk Village, Kaliajeng finally did not join the program. Unfortunately, the equipment such as water meters and pipes built in Kaliajeng are now not used. Kaliajeng eventually lobbied a hamlet in a neighboring village to get water allocation outside the PAMSIMAS program.

Meanwhile, because water mobilization is also related to property rights, Pulihan had to compromise with the national park agency to access water from the park's zones. In this case, the state has more power because the forest and its resources belong to the state (Lunstrum, 2013). The government agency of national park has once stated their willingness to take over the water management. After one of the staff learned that water service revenue was quite significant, especially that which was paid by the social foundation,the national park agency tried to capture this opportunity. Responding to this move, Pulihan tried to lobby the agency to keep managing the park's water resources. Fortunately, thanks to a resident of Pulihan who was working for the national park agency, the agency was still willing to accommodate Pulihan's aspirations. Thus, without having state's recognition on joint ownership over forest resources, Pulihan remained facing uncertainty regarding water access to the national park zone.

\section{Research Implication}

Management of common-pool resources, such as forests and water, always requires appropriate institutions. Common-pool resources refer to goods or services in which users compete highly to use them or find it difficult or expensive to restrict other users from using them (Ostrom, 2015). Institutions are the 'rules of the game' limiting human action and influencing social behavior (North, 2016). The rule itself has some dimensions that define the flow of income and costs and give authority to the decision-making process. Those dimensions affect the distribution of assets and power. Although not always efficient, institutions can reduce uncertainty because rules can control individuals' and organizations' decision-making processes (Schotch, 2018). Therefore, institutions are substantial since the level of certainty and sustainability will, in turn, enable cooperation and create community economic development.

There are two critical institutions for the management of common-pool resources: (i) those that provide coordination and (ii) property rights (Meinzen-Dick, 2014). Coordination is needed to arrange a particular approach to resource management. Coordination function can be provided by the state, collective action, or markets. At the same time, property rights institutions are needed to define the benefit stream of water resources, including access, management, distribution, and exclusion. Many resources are held under certain property rights regimes, which may combine the characteristics of two or more of these types: open-access control (no management intervention), private property (marketbased system), state property (managed by the central government/state), and common property (controlled by the identifiable community based on local rules) (Everard \& Dupont, 2018).

PAMSIMAS encourages community-based drinking water supply and sanitation, so the coordination institution for collective action stands out in this program. Collective action refers to actions taken together by a group of people whose goal is to improve their condition and achieve common goals (Ostrom, 2015). However, in achieving the common goal, the actors in the collective action may follow the rules that exist or just do the opposite, such as 
engaging in opportunistic behavior (Hardin, 2015). Thus, successful water resources management through collective action requires institutional arrangements and certain characteristics of the resource system, water user groups, and a supportive external environment (Ostrom, 2015). And one of the most significant is that property rights should be well defined (Everard \& Dupont, 2018). Property rights will determine whether or not uncertainty can be reduced, and resource management will be sustainable.

The case study's results indicated that two institutional arrangements intersect with the implementation of PAMSIMAS in the research location. Firstly, the property system change strengthens the determination of the national park, where the place of the springs for the PAMSIMAS program is located. Determining the status of Mount Merbabu as a national park means maintaining state property, which also means strengthening the state's power (Lunstrum, 2013). On the other hand, the surrounding rural communities acknowledge riparian rights through which they believe that the water source closest to their hamlet is their right (Craig, 2012). Secondly, coordinating rules for resource management are agreed in PAMSIMAS. The main rules are adopting the water price mechanism, the obligation to use meter technology, and the establishment of BPSPAMS as the new collectivechoice body. The rule of water prices in PAMSIMAS has increased water availability because the mechanism encourages users to use water efficiently (Narasimhan, 2016). Interestingly, village administration's role in this regard was completely absent, especially in defining broader "rules of game" as a reference for operational rule-making by PAMSIMAS in managing water resources. The "absence" of the village government in managing water resources has a context in the local political dynamics, namely the public authorities at the lowest level are already politicized in such a way of held hostage by local political interests during the village head election event (Istiyani, 2014).

Furthermore, the study results also showed several inequalities in the program implementation, namely inequalities in bio-physical condition, power, and information. The difference in biophysical locations among hamlets significantly impacts water access, either weakening or strengthening their capacity to control its distribution. The strategic positions that actors have in water user groups also influence the power and information they get. A group of water users has more chances to participate in the project's decision-making, enabling them to control the project more strongly (García \& Bodin, 2019). The inequalities coupled with local elites' opportunistic behavior have hindered equal cooperation between water users (Baland \& Platteau, 2018). The case shows that the group with more endowments will get more benefits from the program (Kurian \& Dietz, 2013).

Even though rules have helped rural communities to increase water availability, PAMSIMAS cannot reduce the uncertainty of water access and transaction costs borne by water users. The group of users who have fewer endowments has to deliver higher transaction costs. They have to lobby groups with higher endowments to keep access to water. Thus, user groups with lower endowments are trapped in uncertain conditions regarding their secured access to water (Baland \& Platteau, 2018).

Given this situation, the presence of public authority at the local level to resolve disputes, define the public goods, and mediate conflicting interests among community members is necessary. In fact, such authority falls under "the principle of subsidiarity" as stated in the Law no. 6 of 2014 concerning Village. This principle, along with the "principle of recognition", gives the village administration a wide range of authority to govern and make decisions on public matters at the local scale to achieve the maximum prosperity of the community (Shohibuddin, 2016; Shohibuddin et al., 2017).

Unfortunately, the village government's absence in governing water access and issuing village regulation had resulted in a win-lose scenario among different groups of water users having conflicting interests regarding water distribution. Such scenario was finally pursued by Pulihan hamlet as they demanded a tariff increase of 5,000 rupiahs per month from water users in Kaliajeng hamlet. This increase was justified by the required costs for financing the reparation and construction of water pipes. However, the group of water users in Kaliajeng hamlet objected such demand and deemed it as a unilateral decision, so they were unwilling to pay. Following this, Pulihan then decided to stop the distribution of water to Kaliajeng hamlet. As a result, after five years of PAMSIMAS, water access for the low endowment group was cut off, so that all equipment that have been invested in the program has been stalled and abandoned. 
On the other hand, property system of forest and water resources also explains how the uncertainty of water access and transaction costs remain continued (Williamson, 2015; Womble \& Hanemann, 2020). There is an overlapping and even conflicting situation in the property system concerning land and water resources in the national park area, namely stateproperty as defined by national law and common property based on riparian rights as recognized by local rural communities. Furthermore, the undefined forest land boundaries have led to uncertain institutions of coordination in water management, not only for PAMSIMAS program but also for the village administration in general.

Based on the results of the case study, there are several research implications that we can draw. First, water usage charging in PAMSIMAS can increase water availability for more users, but the important issue that requires attention is the rational and appropriate pricing. Pricing needs to integrate public interest and economic benefits applicable to the project (Chen et al., 2013). This also means that the determination of water usage charging must pay attention to water users' interests related to the ease of access to water and cost recovery for maintaining water infrastructure (Narasimhan, 2016).

Secondly, in determining water usage charging based on water user's interests, local regulation and village governance which can provide broader "rule of game" in the water management should be put in place. This will require the village administration's active engagement in resolving disputes, enhancing public goods, and mediating conflicting interests. Doing so would not let the rule-making process in PAMSIMAS program be greatly determined by some sort of "free fight" mechanism.

Thirdly, policymakers need to recognize the importance of understanding the biophysical conditions, institutions, and attributes of communities in the project area (Ostrom, 2015). Inequality of biophysical conditions, including land ownership, is a structural condition that constitutes a challenge both to conservation and development agendas; thus, it must be fully considered in the policy-making process (Benra \& Nahuelhual, 2019). The water management policies under PAMSIMAS in the study area ignored the ownership gap among hamlets and groups' heterogeneity. Mobilization of water resources (as a prerequisite for markets or market-like institutions) in Tajuk is intricate, so ignoring this will require the water users to bear higher transaction costs. Implementing sensitive and flexible water management based on local conditions and prospects while strengthening local administration may protect the future of rural communities and the resources they depend (Rejekiningrum \& Kartiwa, 2018).

Fourthly, government's recognition of common property rights is essential to provide rural communities with incentives and opportunities to manage their resources sustainably in the long run. Mobilization of collective action in resource management depends significantly on property rights, which must be well defined (Everard \& Dupont, 2018). The massive lobbying activities carried out by the local community and the national park government agency indicate the uncertainty of water rights for the communities (Williamson, 2019). Therefore, it is vital to recognize communities' rights and to determine water sources and forest resources' boundaries. Gunawan et al. (2013) suggested establishing a buffer zone that can solve the conflict between conservation agenda and surrounding rural communities' needs, along with increasing community-based management and utilization of environmental services of water and ecotourism. Besides, a public domain for rural communities and national parks is essential to build communication and dialogue about conservation policies and rural communities' welfare.

Fifthly, because PAMSIMAS is a community-based program, community participation should be at the center of its implementation (Asminar, 2019). The case study showed the degree of group participation in the decision-making process will influence program implementation. Thus, initial knowledge about the actors and their strategic positions is essential to ensure their influence and interests and to deal with such power imbalances. Encouraging genuine participation across actors in different groups will bring greater impacts and reduce power and information asymmetries (García \& Bodin, 2019). Also, regular participatory monitoring and evaluation of the program are essential (Pratama \& Isnanik, 2018) to ensure PAMSIMAS providing more sustainable water and sanitation in rural areas.

\section{CONCLUSION AND SUGGESTION}

The study, which focuses on such sensitive areas as national parks, disclosed some critical issues in community-based water management. The 
government-directed rule in PAMSIMAS program, namely the setting of water price (a market-like mechanism), has helped local communities improve the more efficient use of water and increasing water availability. However, PAMSIMAS program cannot reduce uncertainties in water access and transaction costs that the water users should bear due to two categories of inequalities. The first is due to different biophysical conditions and asymmetry of power and information among community members, which would inevitably influence PAMSIMAS program's performance. The second is inequalities resulting from conflicting property systems regarding land and water inside Mount Merbabu National Park, i.e., between state-property regime and common property regime. Thus, It has impacted as well on uncertainties in water access and transaction access.

By highlighting these two categories of inequality, this study suggests that the rule-making regarding water management in PAMSIMAS program prioritizes rational and legitimate pricing by considering both economic benefits and public interests. The recognition of local characteristics must be incorporated into water management policies, including the biophysical conditions and different attributes of communities in a project area. To ensure the balance between different water management priorities, it is suggested that the village government exercises its broad range of authority to govern "localscale matters", especially by issuing relevant village regulations and carrying out the effective governance of local natural resources. Furthermore, government's recognition of common property rights is essential to provide incentives and opportunities for local communities to manage their resources sustainably. Last but not least, since PAMSIMAS is a communitybased program, genuine and inclusive participation among community members must be the primary concern throughout its implementation.

\section{REFERENCES}

Arifin, B. (2006). Transaction cost analysis of upstream-downstream relations in watershed services: Lessons from community-based forestry management in Sumatra, Indonesia. Quarterly Journal of International Agriculture, 45(4), 361375 Retrieved from https://www.agrar.huberlin.de/de/institut/departments/daoe/publ/qjia/ contents/2006/4-06/arifin.htm
Asminar, A. (2019). Partisipasi dan swadaya masyarakat dalam rangka menyukseskan Pamsimas III di Kabupaten Bungo, Provinsi Jambi. Journal of Regional and Rural Development Planning, 3(1), 35. https://doi.org/10.29244/jp2wd.2019.3.1.35-46

Baland, J. M., \& Platteau, J.-P. (2018). Collective action on the commons: In Inequality, Cooperation, and Environmental Sustainability. Princeton University Press (pp. 10-35). https://doi.org/10.2307/j.ctv301grk.5

Bardhan, P., Ghatak, M., \& Karaivanov, A. (2018). Inequality and Collective Action. In Inequality, Cooperation, and Environmental Sustainability. Princeton University Press (pp. 36-59). https://doi.org/10.2307/j.ctv301grk.6

Benra, F., \& Nahuelhual, L. (2019). A trilogy of inequalities: Land ownership, forest cover and ecosystem services distribution. Land Use Policy, 82 247-257. https://doi.org/10.1016/j.landusepol.2018.12.020

Chaerunissa, C. (2014). Partisipasi masyarakat dalam program penyediaan air minum dan sanitasi berbasis masyarakat (Pamsimas) Di Kabupaten Brebes. Politika: Jurnal Ilmu Politik, 5(2), 99-113. https://doi.org/10.14710/politika.5.2.2014.99-113

Chen, Z., Wang, H., \& Qi, X. (2013). Pricing and water resource allocation scheme for the south-to-north water diversion project in China. Water Resources Management, 27(5), 1457-1472. https://doi.org/10.1007/s11269-012-0248-1

Coggan, A., Buitelaar, E., Whitten, S., \& Bennett, J. (2013). Factors that influence transaction costs in development offsets: Who bears what and why? Ecological Economics, 88, 222-231. https://doi.org/10.1016/j.ecolecon.2012.12.007

Craig, R. K. (2012). Defining riparian rights as "property" through takings litigation: Is there a property right to environmental quality? Environmental Law, 42(1), 115-155. Retrieved from https://www.jstor.org/stable/43267514?seq=1

Curry, N. (2009). National parks. In International Encyclopedia of Human Geography (pp. 229-235). https://doi.org/10.1016/B978-0080449104.00576-9

De Pourcq, K., Thomas, E., Arts, B., Vranckx, A., LéonSicard, T., \& Van Damme, P. (2017). Understanding and resolving conflict between local communities and conservation authorities in Colombia. World Development, 93, 125-135. https://doi.org/10.1016/j.worlddev.2016.12.026 
Deng, X., Song, X., \& Xu, Z. (2018). Transaction costs, modes, and scales from agricultural to industrialwater rights trading in an Inland River Basin, Northwest China. Water (Switzerland), 10(11). https://doi.org/10.3390/w10111598

Dunggio, I., \& Gunawan, H. (2009). An overview on the history of national park management policy in Indonesia. Jurnal Analisis Kebijakan Kehutanan, 6(1), 43-56. Retrieved from https://ejournal.forda-mof.org/ejournallitbang/index.php/JAKK/article/view/338

Everard, M., \& Dupont, N. A. (2018). Property rights. In The Wetland Book: I: Structure and Function, Management, and Methods (pp. 981-986). https://doi.org/10.1007/978-90-481-9659-3_188

Fitriyani, N., \& Rahdriawan, M. (2015). Evaluasi pemanfaatan air bersih Program Pamsimas Di Kecamatan Tembalang. Jurnal Pengembangan Kota, 3(2), https://doi.org/10.14710/jpk.3.2.80-89

García, M. M., \& Bodin, Ö. (2019). Participation in multiple decision making water governance forums in Brazil enhances actors' perceived level of influence. Policy Studies Journal, 47(1), 27-51. https://doi.org/10.1111/psj.12297

Gunawan, H., Bismark, M., \& Krisnawati, H. (2013). Kajian sosial ekonomi masyarakat sekitar sebagai dasar penetapan tipe penyangga Taman Nasional Gunung Merbabu, Jawa Tengah. Jurnal Penelitian Hutan Dan Konservasi Alam, 2013(2), 103-119. https://doi.org/10.20886/jphka.2013.10.2.103119

Hardin, R. (2015). Collective action. In Collective Action. RFF Press. 268p. https://doi.org/10.4324/9781315044330

Istiyani, A. (2014). Dinamika pengelolaan sumber daya air di era otonomi daerah studi kasus di Desa Tajuk, Kec. Getasan , Kab. Semarang. Kritis, 23(2), 109-130. https://doi.org/ 10.24246/kritis.v23i2p109-130

Kurian, M., \& Dietz, T. (2013). Leadership on the commons: wealth distribution, co-provision and service delivery. Journal of Development Studies, 49(11), $1532-1547$ https://doi.org/10.1080/00220388.2013.822068

Laurenceau, M., Destandau, F., \& Rozan, A. (2009). A transaction cost approach to assess the Water Framework Directive implementation. WIT Transactions on Ecology and the Environment, 125, 567-578.
Li, T. M. (2016). Governing rural Indonesia: Convergence on the project system. Critical Policy Studies, 10(1), 79-94. https://doi.org/10.1080/19460171.2015.1098553

Lightfoot, G., \& Wisniewski, T. P. (2014). Information asymmetry and power in a surveillance society. Information and Organization, 24(4), 214-235. https://doi.org/10.1016/j.infoandorg.2014.09.001

Lunstrum, E. (2013). Articulated sovereignty: Extending Mozambican state power through the Great Limpopo Transfrontier Park1. Political Geography, 36, 1-11. https://doi.org/10.1016/j.polgeo.2013.04.003

Lunstrum, E. (2014). Green militarization: Antipoaching efforts and the spatial contours of Kruger National Park. Annals of the Association of American Geographers, 104(4), 816-832. https://doi.org/10.1080/00045608.2014.912545

McCann, L. (2013). Transaction costs and environmental policy design. Ecological Economics, 88, 253-262. https://doi.org/10.1016/j.ecolecon.2012.12.012

Meinzen-Dick, R. (2014). Property rights and sustainable irrigation: A developing country perspective. Agricultural Water Management, 145, 23-31. https://doi.org/10.1016/j.agwat.2014.03.017

Meinzen-Dick, R., Raju, K. V., \& Gulati, A. (2002). What affects organization and collective action for managing resources? Evidence from canal irrigation systems in India. World Development, 30(4), 649-666. https://doi.org/10.1016/S0305750X(01)00130-9

Mukherjee, A. (2009). Conflict and coexistence in a National Park. Economic and Political Weekly, 44(23), 52-59. Retrieved from https://www.jstor.org/stable/40279086?seq=1

Narasimhan, S. (2016). Water Pricing: Potential and problems. International Journal of Agricultural Economics and Management, 6(1), 2277-3215. Retrieved from https://www.ripublication.com/ ijaem16/ijaemv6n1_02.pdf

Njiraini, G. W., Thiam, D. R., \& Coggan, A. (2017). The analysis of transaction costs in water policy implementation in South Africa: Trends, determinants and economic implications. Water Economics and Policy, 3(1). 1650020-1-30. https://doi.org/10.1142/S2382624X1650020X

North, D. C. (2016). Institutions and economic theory. The American Economist, 61(1), 72-76. https://doi.org/10.1177/0569434516630194 
Ntuli, H., \& Muchapondwa, E. (2017). Effects of wildlife resources on community welfare in Southern Africa. In Ecological Economics (Vol. 131, pp. 572-583). https://doi.org/10.1016/j.ecolecon.2016.09.004

Ostrom, E. (2010). Institutional Analysis and Development: Elements of the framework in historical perspective. Historical Developments and Theoretical Approaches in Sociology, II, 261-288. Retrieved from http://www.eolss.net/samplechapters/c04/E6-99A-34.pdf

Ostrom, E. (2015). Governing The Commons: The evolution of institutions for collective action. In Governing the Commons: The Evolution of Institutions for Collective Action. Cambridge University Press. https://books.google.co.id/ books?id=hHGgCgAAQBA]

Pratama, A. B., \& Isnanik, A. T. (2018). Evaluasi berjalan program penyediaan air minum dan sanitasi berbasis masyarakat. Jurnal Ilmu Administrasi: Media Pengembangan Ilmu Dan Praktek Administrasi, 15(2), 148-162. https://doi.org/10.31113/jia.v15i2.148

Rejekiningrum, P., \& Kartiwa, B. (2018). Institutional development of irrigation management based on the local wisdom in Indonesia. Journal of Socioeconomics and Development, 1(1), 52-62. https://doi.org/10.31328/jsed.v1i1.535

Saam, N. J. (2007). Asymmetry in information versus asymmetry in power: Implicit assumptions of agency theory? Journal of Socio-Economics, 36(6), 825-840. https://doi.org/10.1016/j.socec.2007.01.018

Sandlos, J. (2007). Federal spaces, local conflicts: national parks and the exclusionary politics of the conservation movement in Ontario, 1900-1935. Journal of the Canadian Historical Association, 16(1), 293-318. https://doi.org/10.7202/015735ar

Schotch, P. K. (2018). Hyperdeontic logic: An overview. In Social Rules: Origin; Character; Logic; Change (pp. 21-34). Taylor and Francis. https://doi.org/10.4324/9780429497278

Shohibuddin, M. (2016). Peluang dan tantangan Undang-undang Desa dalam upaya demokratisasi tata kelola sumber daya alam desa: Perspektif agraria kritis. Masyarakat: Jurnal Sosiologi, 21(1), 1-33. https://doi.org/10.7454/mjs.v21i1.5021

Shohibuddin, M., Cahyono, E., \& Bahri, A. D. (2017). Undang-Undang Desa dan isu sumberdaya alam:
Peluang akses atau ancaman eksklusi? Wacana, 19(36), 29-81. Retrieved from https://insistpress. com/wp-content/uploads/2017/12/Wacana-36Kajian-2-Shohibuddin-Cahyono-Bahri.pdf

Suroso, S. (2018). Implementasi kebijakan pamsimas dalam penyediaan air bersih bagi masyarakatdi Kabupaten Pati. Jurnal Litbang: Media Informasi Penelitian, Pengembangan dan Iptek, 12(1), 3-13. https://doi.org/10.33658/jl.v12i1.47

The World Bank. (2014). PAMSIMAS: Responding to the Water and Sanitation Challenges in Rural Indonesia. 59.World Bank Retrieved from http://documents1.worldbank.org/curated/en/938 961468195535278/pdf/101178-WP-P085375PUBLIC-Box393259B-PAMSIMAS.pdf

Tumusiime, D. M., \& Sjaastad, E. (2014). Conservation and development: Justice, inequality, and attitudes around Bwindi Impenetrable National Park. Journal of Development Studies, 50(2), 204-225. https://doi.org/10.1080/00220388.2013.841886

Vedeld, P., Jumane, A., Wapalila, G., \& Songorwa, A. (2012). Protected areas, poverty and conflicts. A livelihood case study of Mikumi National Park, Tanzania. Forest Policy and Economics, 21, 20-31. https://doi.org/10.1016/j.forpol.2012.01.008

Williamson, O. E. (2015). Transaction costs and property rights. In International Encyclopedia of the Social \& Behavioral Sciences: Second Edition (pp. 528-532). https://doi.org/10.1016/B978-008-097086-8.71023-3

Williamson, O. E. (2019). Transaction-cost economics: The governance of contractual relations. In Corporate Governance: Values, Ethics and Leadership (pp. 133-162). https://doi.org/10.1086/466942

Womble, P., \& Hanemann, W. M. (2020). Legal change and water market transaction costs in Colorado. Water Resources Research, 56(4). https://doi.org/10.1029/2019WR025508

Wray, E. (2019). Indonesia: Expanding access to clean water for the rural poor. World Bank. Retrieved from https://www.worldbank.org/en/results/ 2019/07/29/indonesia-expanding-access-to-cleanwater-for-the-rural-poor

Zhang, L. H., Jia, S. F., Leung, C. K., \& Guo, L. P. (2013). An analysis on the transaction costs of water markets under DPA and UPA auctions. Water Resources Management, 27(2), 475-484. https://doi.org/10.1007/s11269-012-0197-8 